\title{
A Review of Inventory Investment: The Macro and Micro Perspective
}

\author{
Jianyu Huang \\ Jinan University, Guangzhou, China \\ Email: jianyu-huang@163.com
}

Received 19 February 2016; accepted 28 March 2016; published 31 March 2016

Copyright (C) 2016 by authors and Scientific Research Publishing Inc.

This work is licensed under the Creative Commons Attribution International License (CC BY).

http://creativecommons.org/licenses/by/4.0/

(c) (i) Open Access

\begin{abstract}
This article combed the domestic and foreign researches on inventory investment since 1990. We find that researches mainly focus on the macro level of the relationship between inventory investment and business cycle, the effects of inflation or interest rates on inventory adjustment. While in the micro enterprise level, they study the determiners of inventory investment, including financing constraints, size and location. Besides, the role of inventory investment behavior on corporate performance has not yet reached a consensus. Based on the analysis of the existing literatures, we put forward the possible directions for future research in the field of inventory investment, combining with China's specific conditions.
\end{abstract}

\section{Keywords}

\section{Inventory Investment, Business Cycle, Influence Factors}

\section{Introduction}

Inventory is vital for both macro economy and micro enterprises. Accounting for less than 5\% of the GDP fluctuation, inventory investment explains $20 \%$ of the production fluctuation. For the enterprise, inventory holding has both risks and opportunities. Too much inventory holding will generate storage cost and impairment loss, while little may not be able to meet the demand uncertainty in time and thus loss profit margins and market share. Understanding the inventory behavior thoroughly is meaningful to predict the macroeconomic fluctuations and improve the micro enterprise management. The earliest Metzler's (1941) research on inventory behavior demonstrates that an inventory accelerator mechanism can produce cycles in simple Keynesian models. Since then, many scholars have discussed the relation between inventory investment and business cycle, inventory volatility and the output fluctuation, and the internal causes of these relationships.

Blinder \& Maccini (1991) review the earlier empirical and theoretical studies about inventory behavior, and 
they find the paradox that inventories, which are supposed to stabilize production at the micro level, apparently destabilize output at the macro level. The most important stylized facts they point out are: a) production is more variable than sales in most industries, b) sales and inventory investment normally are not negatively correlated, and c) the most volatile components of inventory investment are retail inventories and manufacturers' inventories of raw materials and supplies. These facts doubt the traditional production-smoothing/buffer-stock model to analyze the holding of finished goods inventories by manufacturers. Instead, they regard the $(\mathrm{S}, \mathrm{s})$ model as a better explainer. In later research, most studies explore the theoretical or empirical explanations why production fluctuates more than sales, and what is the purpose of enterprises inventory holding. Another profound research by Ramey \& West (1999), presents a linear-quadratic model to explain the two empirical regularities about inventories: inventory investment is volatile and procyclical, while inventory-to-sales is persistent and countercyclical. Although the literature has not reached a consensus, it has identified mechanisms and forces that can explain basic characteristics of inventory behavior.

In China, study of inventory investment starts relatively late. Due to China's special economic system and gradual marketization, inventory characteristics are different from the European and American countries. Because of the availability of the systematic inventory data, research has been lagging in China. Yi \& Wu (2000) applied H-P filtering method to analyze the inventory investment fluctuation in our country from 1979 to 1989. During the whole time, inventory investment is "counter-cyclical", but if it is divided into several periods, inventory investment has a "procyclical-countercyclical-procyclical" characteristic. They predict that with the improvement of China's marketization, inventory investment is more likely to be procyclical as the mature market economy.

In this paper, we classify the literatures about inventory investment in recent decade, aim to summarize the research situation in this field and we hope to provide a beneficial enlightenment for domestic research on inventory investment. Remainder of this paper is structured as follows. In Section 2, we summarize the existent literatures in the macro level including business cycle, interest rates and inflation. In Section 3, from the micro perspective, we present the determiners of enterprise inventory investment and the relationship with corporate financial performance. In Section 4, we briefly comment on the review and put forward the possible directions for further research, combining with China's specific conditions.

\section{Literatures on the Macro Perspective}

Macro researches are mainly divided into two aspects; one is the characteristics of inventory investment and its relationships with output fluctuation and business cycle. The other is how inflation and real interest rates affect inventory behavior.

\subsection{Inventory Fluctuation and Business Cycle}

There are plenty of researches on inventory investment fluctuation and its relationships with the business cycle with different countries and time series data. Chikán \& Kovács (2009) use the OECD database to analyze inventory trends between 1987 and 2004 in nine of the most developed economies of the world. Annual inventory investment data are used and their connections with other components of GDP expenditure (governmental and private consumption, investment in fixed assets and foreign trade balance as well as the annual growth rate of GDP) are examined by multi-variable statistical analysis. They find the steadily decreasing tendency of inventory fluctuations, and the varying periods of higher and lower rates of inventory investments. Wen (2005) distinguishes the cyclical frequency and reveals that at very high frequencies like $2-3$ quarters per cycle, inventory investment is strongly countercyclical and production is less volatile than sales. While only at relatively low-cyclical frequencies like 8 - 40 quarters per cycle, inventory investment is procyclical and production is more volatile. Unlike capital investment or GDP, the bulk of the variance of inventory investment is concentrated around high frequencies rather than around business-cycle frequencies. This paper shows that the stockout avoidance theory has much better potential than other competing theories for explaining the seemingly paradoxical features of inventory fluctuations observed at different cyclical frequencies. Using the data of 29 European countries during the "Great Recession" of 2008 to 2009, Yngve \& Jochen (2011) suggest that a fairly uniform pattern emerges. Inventory investment is positively correlated with changes in production and follows the latter with a time-lag of two to three quarters. Very few countries (Austria, Greece, Spain and Switzerland) diverge from the typical pattern. 
In China, Zhang et al. (2010) compile the inventory index of finished goods for the 5000 enterprises, grounded on the 5000 Enterprises Survey conducted by the People's Bank of China. The 5000 Enterprises Inventory Index basically displays the feature of pro-cyclicality and fits the fluctuation of economy with one quarter's lag. It only includes part of enterprises of the whole economy; it may be bias for the constructed inventory index. Later, Xu, Xue, \& Che (2012) using PMI dataset, further investigate inventory investments for both final goods and material goods. They find that the former series is counter-cyclical, while the latter is pro-cyclical. But their model only considers the producer behavior. How to join the family behavior model to a complete general equilibrium model for China's economy is the future research direction.

Lin (2010) separates China's economic fluctuation into domestic final consumption expenditure fluctuations and import and export trade in goods, respectively reflect economic fluctuation with the domestic market and international market. Results show that China's inventory investment fluctuation is closer with the international market relative to the domestic market, reflecting there exists a gap in respect of marketization in Chinese economy. Lv (2014) takes listed manufacturing companies as samples and breaks inventory investment down into trend items and periodic items by H-P filter. He finds out a significant positive correlation between inventory investment and operation revenue, but a significant negative correlation in the short term.

To sum up, inventory is overall pro-cyclical and positive with production fluctuations. Also there is a declined tendency accompanied with the improving technology of inventory management and accurate demand prediction. We should notice that characteristics of inventory investment varies across countries, periods, cyclical frequencies, industries and components including raw material, work-in-progress and finished goods.

\subsection{Real Interest Rates and Inflation}

Maccini, Moore, \& Schaller (2004) present a model based on regime switching of the real interest rate and learning. They find that inventories tend to be lower when the economy is in the high-interest-rate regime. On this basis, Binvin (2010) extends the MMS model to work-in-process and raw material inventories as well as industries that produce to order and has the reinforced results. However, Benati and Lubik (2014) use Bayesian time-varying VAR methods to study the connection, and find that the positive correlation between inventories and interest rates is robust over the entire sample, especially positive for the post-World War II period while it's negative in the inter-war period. They argue that an interest rate shock causes a positive or a negative change in inventories crucially hinges upon the recessionary effect or planned decrease effect dominates. Maccini, Moore, \& Schaller (2015) build a model with permanent sales shocks, initially structure a conditional variance ratio (conditional on past production and sales), which give explanations for Sign Puzzle ${ }^{1}$ and Timing Puzzle ${ }^{2}$ successfully. That is, stimulative monetary policy reduces the interest rate, enhance sales, but lower inventories because of the role of buffer-stock. Enterprises take time to learn the persistent regime change of interest rate so that inventories rise years after the interest rate declining.

When comes to the relation between inflation and inventory, Yu et al. (2005) use the annual data from 1978 to 2002 and show that inventory is sensitive to inflation, but inflation is not sensitive to inventory. They imply speculation in business is prevalent in China. Furthermore, Rao et al. (2013) empirically demonstrate that expected inflation affects firms' inventory investment positively. They also find that the adjustment for expected inflation leads to better financial performance only when the expectation of inflation is accurate. Defining different stages of inflation cycle, Yang et al. (2015) investigated the specific characteristics of firm's inventories adjustment and their varieties across industries. Surprisingly, the adjustment of firm's inventories is counter-inflation cycle and to most industries, the monetary policies are invalid in low inflation stage. The threshold of effective inflation mechanism is $3.4 \%$.

Although these literatures do not reach a consensus, they do combine the macro factors such as interest rate and inflation with the micro enterprises inventory behaviour, and therefore shed some lights on the frame of relationship between macro policy and micro activities and provide reference to the policy maker.

\section{Literatures on the Micro Perspective}

Micro-level researches on inventory investment behavior are relatively less, mainly about the influence factors

${ }^{1}$ Stimulative monetary policy reduces the interest rate and should, therefore, increase inventories. However, VAR studies find that the short-term effect of stimulative monetary policy is to decrease inventories.

${ }^{2}$ The peak effect of the monetary policy shock on inventories occurs years after the shock. 
of enterprise inventory and its economic consequences.

\subsection{Influence Factors}

In addition to the classical theory of cost shock (technology, capital or labour), demand shock, and financial shock (interest rates), inventory investment is also influenced by the characteristics of enterprise.

Firstly, financial strenght is under consideration, including inner cash flow and capital cost. Carpenter et al. (1998) compare the empirical performance of different financial variables (coverage ratio, cash stocks, and cash flow) within a high-frequency (quarterly) firm panel data. They find cash flow is much more powerful than cash stocks or coverage in explaining the facts about inventory investment, no matter in different firm size, different inventory cycles, or different manufacturing sectors. Jones \& Tuzel. (2013) examine the relation between inventory investment and the cost of capital in time series and the cross section. They provide consistent evidence that risk premiums, rather than real interest rates, are strongly negative to the future inventory growth at the aggregate, industry, and firm levels. The effect is stronger for firms in industries that produce durables, exhibit greater cyclicality in sales, require longer lead times, and are subject to more technological innovation.

Secondly, it comes to firm size and location. Using a sample of 2544 Greek manufacturing firms, Dimelis \& Lyriotaki (2007) provide new evidence with respect to the role of size and foreign ownership in determining inventory behavior. The larger a firm and the higher the foreign proportion in its capital, the lower level of inventory investment is kept in each period. Firm location is considered in a recent study (Lai et al., 2010). Employing a panel data set of 1531 listed firms, they conclude that city and province jointly explain one quarter of the variance in inventory turn. Another paper (Robb et al., 2012) review inventories in mainland China by evaluating the trajectory of aggregate inventories in recent decades, and then modelling the relationship of inventories in some 300,000 manufacturers with respect to volume (using cost of goods sold), industry (using SIC codes), and geographical location (using the 31 regions of China). They find that inventories generally exhibit economies of scale in all but one industry (tobacco), and differ widely by province, with relatively high inventories in remote regions.

\subsection{Financial Performance}

Enterprise behavior will certainly lead to some economic consequences. How inventory investment changes affect the enterprise's financial performance, scholars have launched a widely discussed and have made different conclusions. Xu \& Yao (2008), based on 1998 to 2004 listed firms dataset, suggest that the relationship between financial performance and inventory turnover can be characterised as an inverted-U shape. In the same year, Cannon (2008) indicated no link between improvements of inventory performance and overall firm performance. However, Capkun et al. (2009), also using the data of listed US manufacturing firms but for the period of 1980 to 2005, show a positive relationship between inventory performance and financial performance. Eroglu and Hofer (2011) reveals that the significance and shape of the inventory-performance relationship varies substantially across industries. In most of these instances, the relationship is concave, suggesting that there is an optimum level of inventory leanness beyond which firm performance deteriorates. While Pong \& Mitchell (2012) use 1986-2005 UK companies data, find that improved inventory control generally leads to inventory decrease, and thus firms have a better corporate performance.

In my opinion, enterprise inventory investment behavior is complex and influenced by many aspects, such as the CEO's risk preference, the enterprise market position or some other financial or non-financial characteristics of companies. It remains further research to provide more empirical evidence. Since there is no definitely good or bad about inventory investment and direction of the inventory adjustment could be positive or negative, the impact of inventory investment on corporate performance is debated. I think the most important thing is to find an appropriate way to judge and proxy the beneficial inventory investment for company performance combining the macro background.

\section{Conclusion}

This paper analyzed domestic and foreign resarches since 1990 about inventory investment from the macro and micro perspective. In the macro level, we know that the inventory is decreasing, pro-cyclical and positive with output fluctuations. Meanwhile, production smoothing is no longer the main motive for inventory holding. In addition, studies should take different components of inventory into account as they reflect significant variety. 
Relationships between inflation or interest rates and inventory investment also need further discussion. From the micro perspective, studies find that the enterprise's financial strength, including cash flow, solvency and the cost of capital will affect the enterprise inventory behavior. Besides, the size, foreign capital attribution and the location of the enterprise also have a role in its inventory behavior. Personally, I consider the influences of the financial constraints and the location are associated with the degree of marketization in China which has been mentioned by Yi \& Wu (2000). Since the macro environment will affect the enterprise behavior, medium level of market environment such as market competition, market status of enterprises or industry characteristics, should also have impacts on enterprise inventory investment behavior. But the influence mechanism is not clear yet, maybe it's a possible direction for the future research on inventory investment.

\section{References}

Benati, L., \& Lubik, T. A. (2014). Sales, Inventories and Real Interest Rates: A Century of Stylized Facts. Journal of Applied Econometrics, 29, 1210-1222. http://dx.doi.org/10.1002/jae.2408

Binvin, D. G. (2010). Inventories and Interest Rates: A Stage of Fabrication Approach. B.E. Journal of Macroeconomics, 10, 29-29.

Blinder, A. S., \& Maccini, L. J. (1991). Taking Stock: A Critical Assessment of Recent Research on Inventories. Journal of Economic Perspectives, 5, 73-96. http://dx.doi.org/10.1257/jep.5.1.73

Cannon, A. R. (2008). Inventory Improvement and Financial Performance. International Journal of Production Economics, 115, 581-593. http://dx.doi.org/10.1016/j.ijpe.2008.07.006

Capkun, V., Hameri, A. P., \& Weiss, L. (2009). On the Relationship between Inventory and Financial Performance in Manufacturing Companies. International Journal of Operations and Production Management, 29, 789-806. http://dx.doi.org/10.1108/01443570910977698

Carpenter, R., Fazzari, S. M., \& Petersen, B. C. (1998). Financing Constraints and Inventory Investment: A Comparative Study with High-Frequency Panel Data. Review of Economics and Statistics, 80, 513-519. http://dx.doi.org/10.1162/003465398557799

Chikán, A., \& Kovács, E. (2009). Inventory Investment and GDP Characteristics in OECD Countries. International Journal of Production Economics, 118, 2-9. http://dx.doi.org/10.1016/j.ijpe.2008.08.004

Dimelis, S. P., \& Lyriotaki, M. N. (2007). Inventory Investment and Foreign Ownership in Greek Manufacturing Firms. International Journal of Production Economics, 108, 8-14. http://dx.doi.org/10.1016/j.ijpe.2006.12.045

Eroglu, C., \& Hofer, C. (2011). Lean, Leaner, Too Lean? The Inventory-Performance Link Revisited. Journal of Operations Management, 29, 356-369. http://dx.doi.org/10.1016/j.jom.2010.05.002

Jones, C. S., \& Tuzel, S. (2013). Inventory Investment and the Cost of Capital. Journal of Financial Economics, 107, 557579. http://dx.doi.org/10.1016/j.jfineco.2012.09.001

Lai, R., Robb, D., \& Ren, Z., (2010). The Geography of Chinese Inventory. Working Paper, The Wharton School, the University of Pennsylvania, Philadelphia.

Lin, F. B. (2010). On the Problem of Excess Production Capacity from the View of Fluctuation of the Inventory Investment. Asia-Pacific Economic Review, 2, 115-118.

Lv, F. Y. (2014). Periodic Relationship between Inventory Adjustment and Output Volatility: Research Based on the Data of Listed Manufacturing Companies. On Economic Problems, 3, 76-82.

Maccini, L. J., Moore, B. J., \& Schaller, H. (2004). The Interest Rate, Learning, and Inventory Investment. American Economic Review, 5, 1303-1327. http://dx.doi.org/10.1257/0002828043052295

Maccini, L. J., Moore, B., \& Schaller, H. (2015). Inventory Behavior with Permanent Sales Shocks. Journal of Economic Dynamics and Control, 53, 290-313. http://dx.doi.org/10.1016/j.jedc.2015.02.010

Metzler, L. A. (1941). The Nature and Stability of Inventory Cycles. Review of Economic Statistics, 23, 113-129. http://dx.doi.org/10.2307/1927555

Pong, C. K. M., \& Mitchell, F. (2012). Inventory Investment \& Control: How Have UK Companies Been Doing? The British Accounting Review, 44, 173-188. http://dx.doi.org/10.1016/j.bar.2012.07.008

Ramey, V. A. \& West, K. D. (1999). Chp13. Inventories. In J. B. Taylor, \& M. Woodford (Eds.), Handbook of Macroeconomics (Vol. 1, pp. 863-923). Dutch: Elsevier.

Rao, P. G., Yue, H., \& Jiang, G. H. (2013). Expected Inflation and Firms’ Inventory Adjustment. Working Paper, Jinan University \& Beijing University.

Robb, D. J., Liu, F., Lai, R., \& Ren, Z. J. (2012). Inventory in Mainland China: Historical, Industry, and Geographic Perspectives. International Journal of Production Economics, 135, 440-450. http://dx.doi.org/10.1016/j.ijpe.2011.08.020 
Wen, Y. (2005). Understanding the Inventory Cycle. Journal of Monetary Economics, 52, 1533-1555. http://dx.doi.org/10.1016/j.jmoneco.2004.10.009

Xu, Z., \& Yao, M., (2008). Inventory Management and Firm Performance: An Empirical Analysis of Listed Chinese Manufacturers. Shantou University Journal (Humanities \& Social Sciences), 24, 60-64.

Xu, Z. W., Xue, H. X., \& Che, D. W. (2012). On the Cyclical Behaviors of Chinese Inventory Investments. Economic Research Journal, 8, 81-92.

Yang, J. Sh., Yang, J. H., \& Wu, X. J. (2015). Inflation Cycle, Financing Constraints and the Dynamic Adjustment Strategies of Firms Inventories. Journal of Management Science, 9, 55-64.

Yi, G., \& Wu, R. H. (2000). Inventory and Production Fluctuations-Theory Review and Preliminary Analysis of the Chinese Situation. Finance and Trade Economics, 6, 17-22.

Yngve, A., \& Jochen, H. (2011). Inventory Investment and Production in Europe During the “Great Recession”: Is There a Pattern? International Journal of Production Economics, 132, 174-177. http://dx.doi.org/10.1016/j.ijpe.2011.03.023

Yu, J., Wang, Z. C., \& Gan, R. C. (2005). Inventory Investment, Inflation and the Business Cycle. Chinese Journal of Management Science, 10, 267-271.

Zhang, T., An, L., \& Chen, H. (2010). 5000 Enterprises Inventory Index and the Fluctuation of Economy. Journal of Financial Research, 7, 35-44. 